\title{
THE COLLECTION OF ANABAPTIST POTTERY OF THE MORAVIAN GALLERY IN BRNO
}

\author{
Andrea HusseInIOvÁ \\ Moravian Gallery in Brno \\ Husova 18, 66226 Brno, Czech Republic \\ E-mail: andrea.husseiniova@moravska-galerie.cz
}

\begin{abstract}
Anabaptist faience is the most important local phenomenon in the history of European ceramics. The holdings of the Moravian Gallery in Brno include a small collection of this pottery type (at present nearly 60 items). The start of this collection goes back to the early years after the founding of the Moravian Industrial Museum, the predecessor of today's Museum of Applied Arts of the Moravian Gallery in Brno. Its core comprises items acquired by the museum as early as in the $19^{\text {th }}$ century. Many of the later acquisitions were originally part of private collections, such as a set of pottery from the collector František Kretz. The oldest dated collection item is a tazza with a perforated rim, bearing a Dietrichstein emblem and the date 1607 . With regards to form there is an obvious prevalence of flat ware. The archaeological excavations carried out in the 1950s by specialists from the Museum of Applied Arts in Vacenovice (Hodonín district) made a significant contribution to research into the manufacture of Anabaptist faience. The outcome of these activities was a large exhibition of Anabaptist faience at the end of 1955 and the start of 1956, accompanied by the publication of two catalogues $(1955,1961)$.
\end{abstract}

Keywords: Anabaptist faience, Moravian gallery in Brno, pottery, Vacenovice

The collection of Anabaptist faience in the holdings of the Moravian Gallery in Brno increased gradually and relatively slowly. The first examples from the rich repertory of this type of pottery were incorporated as part of the exhibits shortly after the founding of the independent Moravian Industrial Museum in 1873 (today the Museum of Applied Arts of the Moravian Gallery). Alongside an unprecedented industrialization boom, the second half of the $19^{\text {th }}$ century brought a new phenomenon - the founding of museums of applied arts as a reflection of economic power in the wake of the dynamic development of machine production and the ambitions, which the ruling classes in the European countries had fulfilled. Together with the accumulation of collections, the museums of applied arts were first and foremost typified by their didactic and educational content and an effort to improve the aesthetic and qualitative level of contemporary industrial production. The core of the Anabaptist pottery collection was formed during the first decades of the museum's existence thanks to the financial support of the state, the Chamber of Commerce and Trade and 
the Moravian Industrial Society, and through direct gifts by individual museum supporters among the German population of Brno - e.g. Alois Naske (1853-1941), city councillor, deputy mayor of the City of Brno and director of the Brno Lower Secondary School donated a bowl dated 1652 (U 3526), Gustav Handschuh, the company secretary of the Brno wool firm Schöller and the grandfather of the mathematician Kurt Gödel, donated a tray dated 1661 (U 6399), Eugenie Marie Barbara Teuber (1841-1914), daughter of E. Soxhlet, owner of a spinning mill in Brno, and wife of the industrialist Wilhelm Josef Teuber, donated to the museum, after the death of her husband, a set of items, among them a medicinal jar dated 1685 (U 5151). ${ }^{1}$ Twenty-two items from the early acquisitions of Anabaptist faience have survived in the collection of the Moravian Gallery to this day. Early acquisitions of Anabaptist faience were also purchased from the local Jewish antiquarians, Wilhelm Grünbaum (1844-1902) ${ }^{2}$ and Solomon Breda (U 6585, U 6586), as well as antiquarians abroad, e.g. in Dresden or Kronstadt, today Braşov (Romania) in Transylvania. A major turning-point came after the establishment of Czechoslovakia in 1918, influencing the internal structure and the general direction of the institution for decades to follow. Julius Leisching, the most significant figure in museum practice in Moravia of that time, a man with a broad outlook and international contacts, was forced to resign from the management. Changes to the museum's administration organisation in favour of Czech representatives led to the breaking of links with German (or more precisely Austrian) financial and business circles. This discontinuity had a negative impact on procuring new acquisitions, and the acquisition policy of the museum through the entire inter-war period suffered decline. There was no substantial improvement to the Anabaptist faience collection until 1924 and the re-organization of the collections of the Moravian Museum, when part of the ceramics collection of the renowned collector, journalist and promoter of folk art František Kretz was transferred to the collections of the Museum of Applied Arts. It also contained a section of Anabaptist pottery, among others a tazza (U 23204, Fig. 2), five albarellos (U 23271, U 23272, U 23515-U 23517), a plate (U 23537) and a teapot with a tray (U 23538, U 23539), which have remained part of the Moravian Gallery collection to this day. In the post-war era, the collection continued to grow mainly through occasional purchases arranged through Antikva Brno, and individual gifts. Among the outstanding acquisitions of Anabaptist pottery we should highlight at least two plates (U 15258, U 15259, Fig. 12) from the collection of the important Brno collector Otakar Vaňura, ${ }^{3}$ and a fragment of a medicinal jar (U 14829) donated by the art historian and ethnographer Růžena Hrbková. ${ }^{4}$ An interesting addition was a small jug (U 29246, Fig. 7) from the private collection of Vladimír Šujan.

\footnotetext{
${ }^{1}$ A plate dated 1688 (inv. n. U 3586) was written off the museum inventory in 1965. A plate with the name Frans Stel dated 1699 (inv. n. U 9388) was probably transferred to the collection of the Moravian Museum in Brno. The item was written off in 1982.

${ }^{2}$ Through W. Grünbaum valuable exhibits from all trades and industries were purchased for the collections of the Museum of Applied Arts of the Moravian Gallery, with regards to Anabaptist faience, specifically a guild jug (U 3988), a cobalt jug dated 1673 (U 4025), a plate with the date 1683 (U 4044) and a tankard (U 9417). W. Grünbaum also supplied examples of pottery of Moravian provenance to the collection of the Ethnographic Museum in Vienna.

${ }^{3}$ More on the collection of Otakar Van̆ura in the Moravian Gallery in NovotnÁ 1992: 23-26.

${ }^{4}$ Other fragments of the same vessel were kept in the collection of the Moravian Museum, to which the fragment originally acquired for the Museum of Applied Arts was transferred in 1982.
} 
More recently the latest acquisitions, a plate (U 30827) and a heart-shaped plate (U 30828, Fig. 11), were purchased for the Moravian Gallery collections in 1994.

An important role in research on Anabaptist pottery was played by the research team of the Museum of Applied Arts in Brno in the 1950s. In the autumn of 1956, the researchers Alena Kudělková and Milena Zeminová started excavating the site of a faience workshop in Vacenovice (Hodonín district), adopting a highly professional approach to the task. ${ }^{5}$ Three excavation campaigns on the site in Vacenovice yielded interesting shard material, which is today kept in the collections of the Historical Museum in Slavkov near Brno. Only three items from the shard material uncovered during the excavations in Vacenovice can be found in the Moravian Gallery collection today - a fragment of a mould for the perforated bowls (U 17037, U 17038, Fig. 5), a fragment of a tray bottom with a stylised bunch of flowers (U 27874, Fig. 4) and a candle holder (U 27873, Fig. 6). Alena Kudělková and Milena Zeminová also organised the first comprehensive thematic exhibition of Anabaptist pottery in the former Czechoslovakia. This broadly conceived project, on show in the exhibition rooms of the Museum of Applied Arts in Brno at the end of 1955 and the start of 1956, brought together for the first time material heritage from public and private collections in Bohemia, Moravia and Slovakia. The curators of the exhibition managed to assemble around 445 exhibits, including earthenware and faience. ${ }^{6}$ The $\mathrm{Mu}-$ seum of Applied Arts, which in the meantime had become part of the Moravian Gallery in Brno, revisited the phenomenon of Anabaptist pottery in 1981. The exhibition titled Habánská fajáns 1590-1730, organized in collaboration with the Museum of Decorative Arts in Prague and the National Gallery, premiered in the Belvedere in Prague Castle. The installation was then transported to Brno and from $9^{\text {th }}$ March to $12^{\text {th }}$ April it was hosted in the Brno House of Arts. ${ }^{7}$ The exhibition was accompanied by the publication of a scientific catalogue of Anabaptist pottery from institutional as well as private collections. The outcome of this presentation, exceptional in its range, was the systematic classification and processing of the material and its re-evaluation.

The collection of Anabaptist pottery from the holdings of the Moravian Gallery, today amounting to almost 60 items, covers virtually the whole production range of this remarkable pottery in terms of form and decor. The exhibits include plates, bowls, jugs, tankards, bottles, medicinal jars, floor tiles and stove tiles, pots, even a candle holder and the most impressive type of Anabaptist tableware - perforated tazzas. A rare item is a fragment of a mould with an arched pattern for the manufacture of perforated trays from the excavation in Vacenovice (U 17037, U 17038, Fig. 5). One of possibly the oldest examples of Anabaptist faience from Moravia is a tazza dated 1607 (U 25517, Fig. 1), which is also the oldest dated item in the Moravian Gallery collection. The more extraordinary exhibits include a restored candle holder from the excavation in Vacenovice with the date 1616 and the name of the customer (U 27873, Fig. 6), a globular jug with the date 1618 (U 29246, Fig. 7) purchased from the private collection of V. Sujan and a floor tile with the Dietrich-

\footnotetext{
${ }^{5}$ A detailed study concerning the excavations in Vacenovice, including evaluation of the archaeological finds, was written by PAJER 1999: 31-54.

${ }^{6}$ KudĚLKová Zeminová 1955.

${ }^{7}$ Kybalová - Novotná 1982. The Prague exhibition opening was accompanied by a two-day seminar held on 8th-9th February 1982 - SCHEUfLeR 1982: 69-70.
} 
stein coat of arms in the centre (U 14044, Fig. 8), originating from a larger collection kept at the chateau in Mikulov. ${ }^{8}$ The second quarter of the $17^{\text {th }}$ century is represented only by a tazza with the date 1634 (U 1172, Fig. 3), while the period from 1650 until the disintegration of the community life of the Anabaptists in 1685 is evidenced in the collection by numerous products of Slovak provenance, including a plate with the initials HGK, dated 1665 and with animal motifs on the rim (U 30827), a melon-like ribbed jug with cobalt glazing and white spiralling tendrils dated 1673 (U 4025), a four-sided bottle with an emblem and the date 1684 (U 1762, Fig. 9), and another remarkable piece is a bottle dated 1675 (U 2216, Fig. 10). In addition, the surviving product range from this period includes flat and hollow ware, examples of jugs, bowls and plates. The final phase from 1710 can be exemplified by a pair of marbled bowls (U 14687, U 14688), a pear-shaped jug with a tin lid, symbols of Christ's passion and the date 1689 (U 14694) and, most importantly, by a set of medicinal jars - albarellos. The period of post-Anabaptist production is represented in the Moravian Gallery collection by a heart-shaped bowl (U 9374, U 30828, Fig. 11), a cylindrical tankard with a cobalt architectural painting complemented by a tin mount and a lid (U 9417, Fig. 13) as well as a jug with guild symbols in a wreath and the date 1732 (U 3988).

In terms of its size, the Moravian Gallery's collection of Anabaptist faience is not the largest institutional set within the Czech Republic, but it does contain some exceptional, high-calibre examples of the Moravian, Hungarian and Slovak stage of the production of this remarkably fine pottery and thus ranks alongside the valuable Czech collections in the National Museum in Prague, the Museum of Decorative Arts in Prague and the Moravian Museum in Brno.

\section{LITERATURE}

FraUberger, Heinrich

1876: Wegweiser durch die Special-Ausstellung für Thonwaaren-Industrie in Mährischen Gewerbe-Museum in Brünn. Brünn.

Horvath, J. Eugene - Krisztinkovich, Maria H.

2005: A History of Haban Ceramics. A Private View. Vancouver.

KudĚLKová, Alena - Zeminová, Milena

1955: Moravská a slovenská habánská keramika [Moravian and Slovak Anabaptist Pottery]. Brno.

1961: Habánská fajáns [Anabaptist Faience]. Prague.

KybalovÁ, Jana - NovotnÁ, Jarmila

1982: Habánská fajáns 1590-1730 [Anabaptist Faience 1590-1730]. Prague.

Novotná, Jarmila

1981: Habánská fajáns z moravských sbírek [Anabaptist Faience from Moravian Collections]. Bulletin Moravské galerie v Brně 31. 37-40.

PAJER, Jiří

1999: Novokřtěnci ve Vacenovicích [The Anabaptists in Vacenovice]. Slovácko XLI. 31-54.

2011: Novokřtěnské fajánse z Moravy 1593-1620 [Anabaptist Faience from Moravia 1593-1620]. Strážnice.

SCHEUfLER, Vladimír

1982: Výstava a seminář o novokřtěnských fajánsích [Exhibition and Seminar on Anabaptist Faience]. Umění a řmesla 4. 69-70.

VYDRA, Josef

1957: Výstava habánské keramiky [Exhibition of Anabaptist Faience]. Umění a řemesla 4. 182-185.

${ }^{8}$ PAJer 2011. 


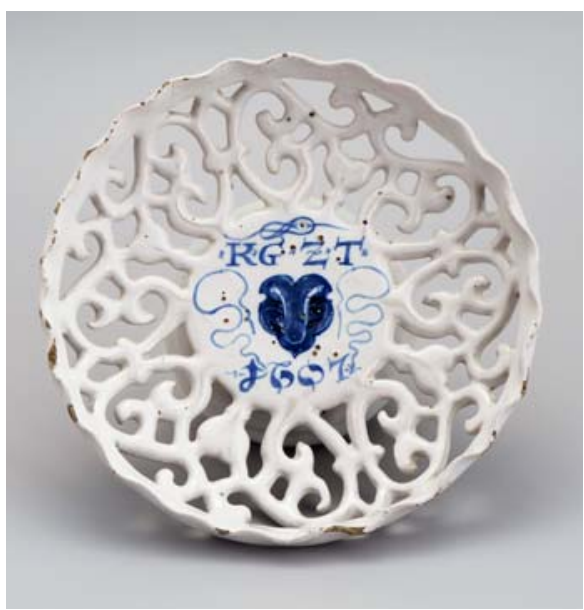

Fig.1. Perforated bowl on stand, 1607, faience, H. $6.9 \mathrm{~cm}, \varnothing 20.5 \mathrm{~cm}$. Inv. n. U 25517

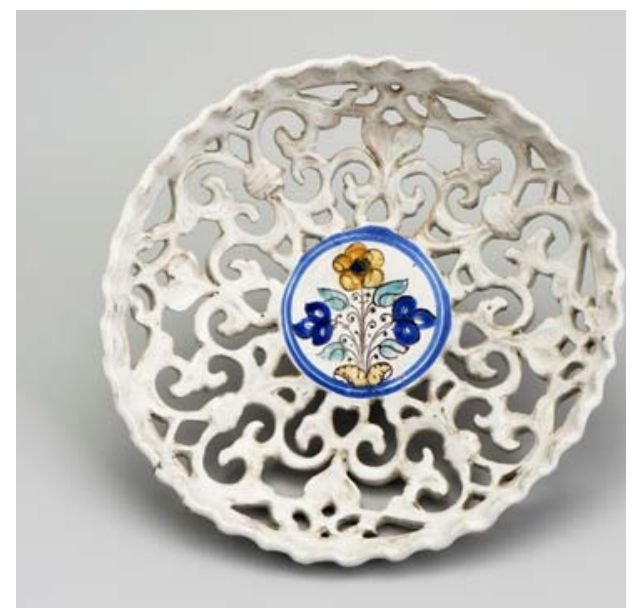

Fig. 2. Perforated bowl on stand, faience, Ø $23.5 \mathrm{~cm}$. Inv. n. U 23204

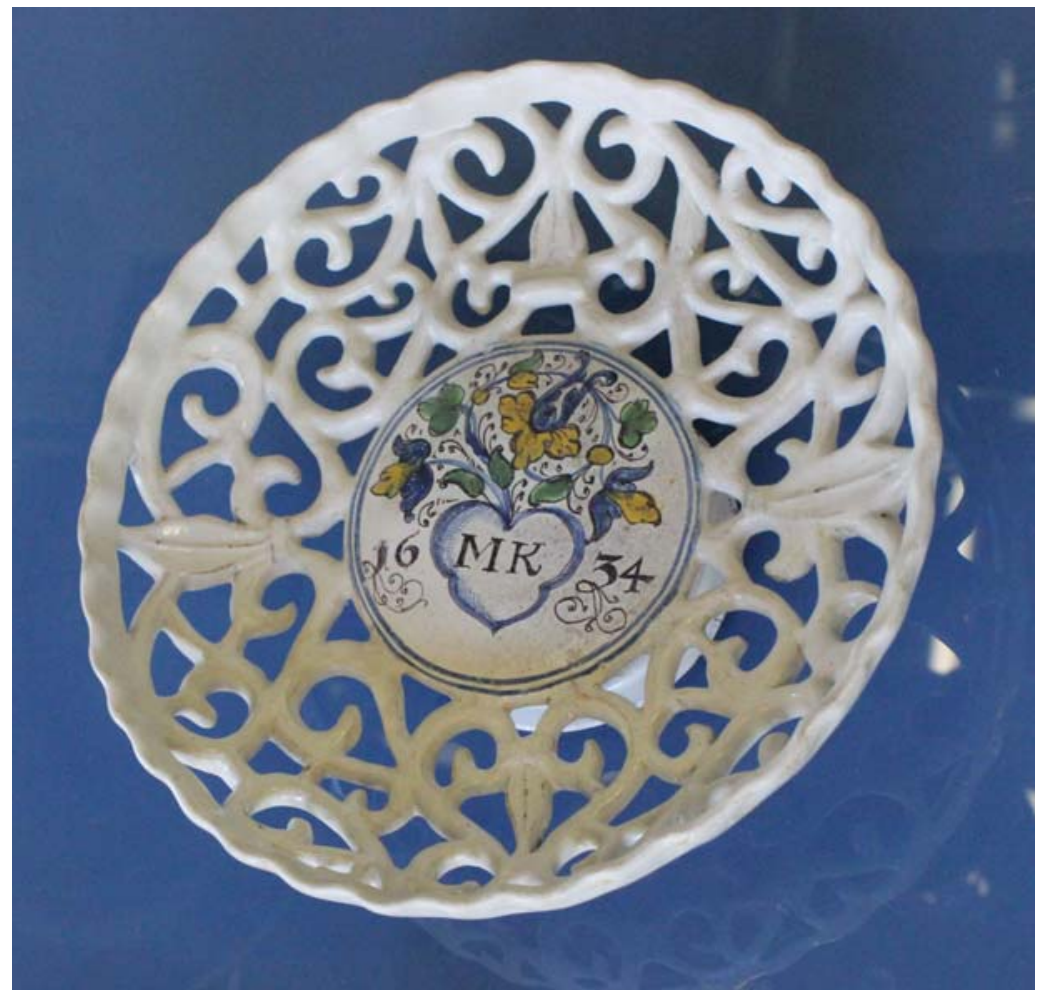

Fig. 3. Perforated bowl on stand, 1634, faience, Ø $19.5 \mathrm{~cm}$. Inv. n. U 1172 


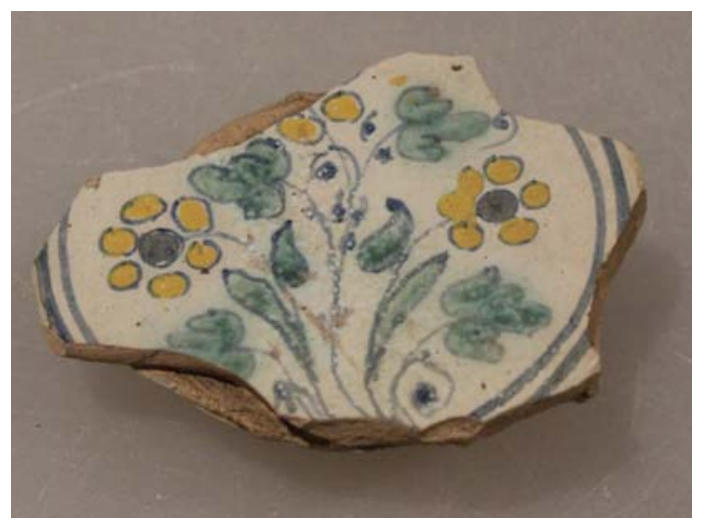

Fig. 4. Fragment of a bowl, faience, Vacenovice, $\varnothing 8.5 \mathrm{~cm}$. Inv. n. U 27874

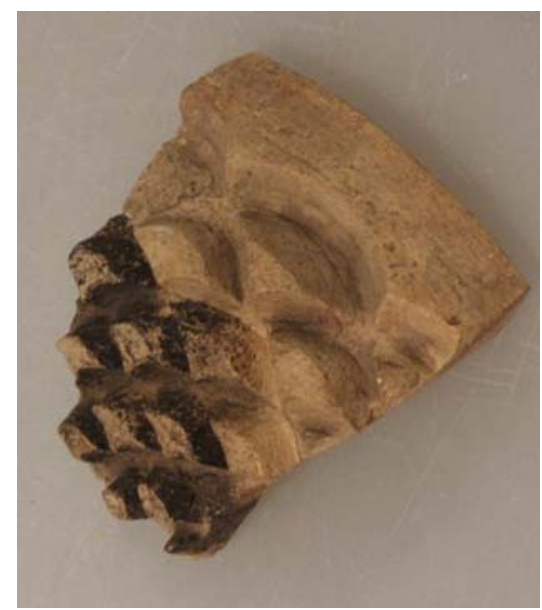

Fig. 5. Fragment of a mould for perforated bowls, Vacenovice, $7 \times 9 \mathrm{~cm}$. Inv. n. U 17037

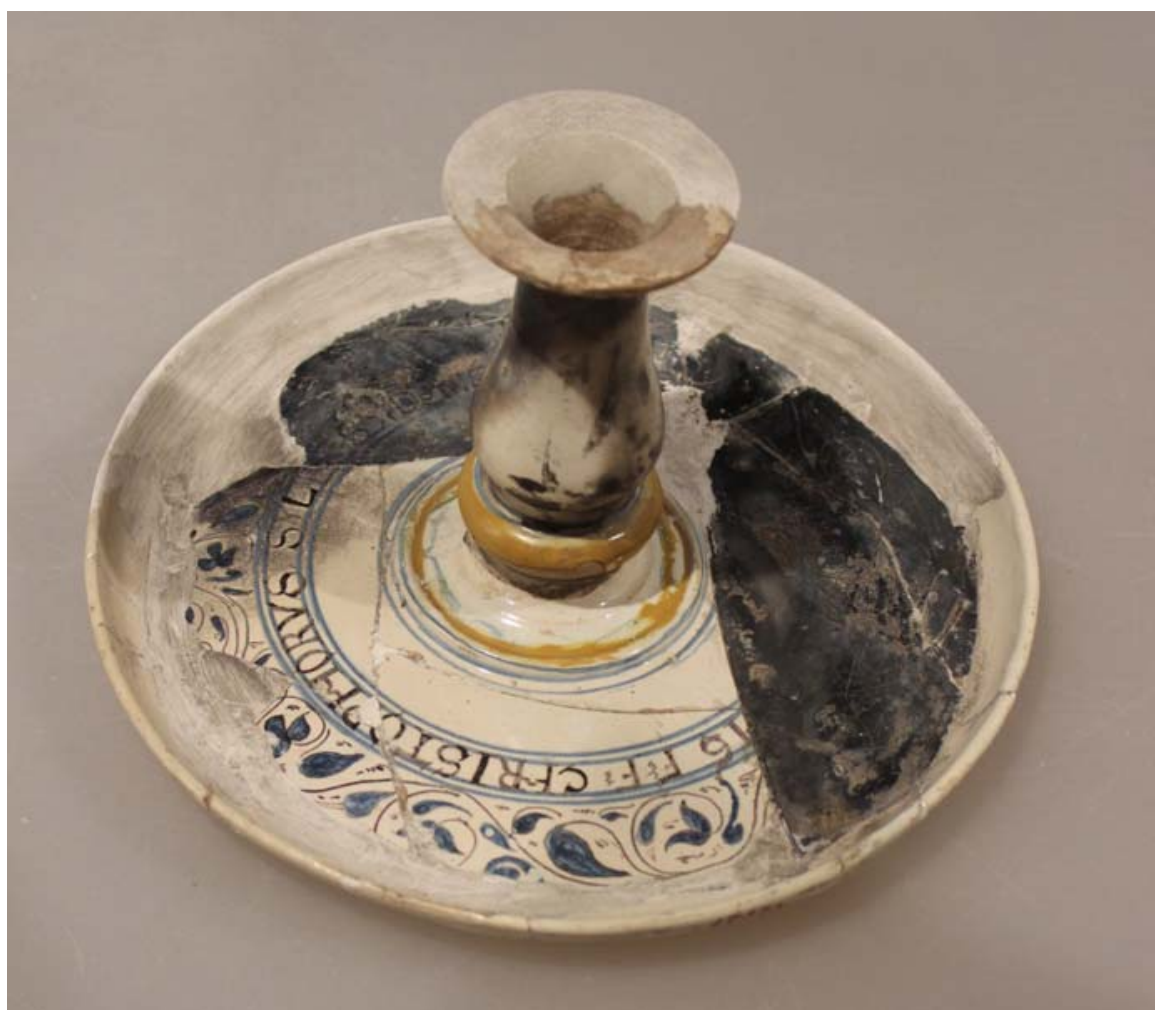

Fig. 6. Reconstructed candle holder, 1616, faience, Vacenovice, H. 12 cm. Inv. v. U 27873 


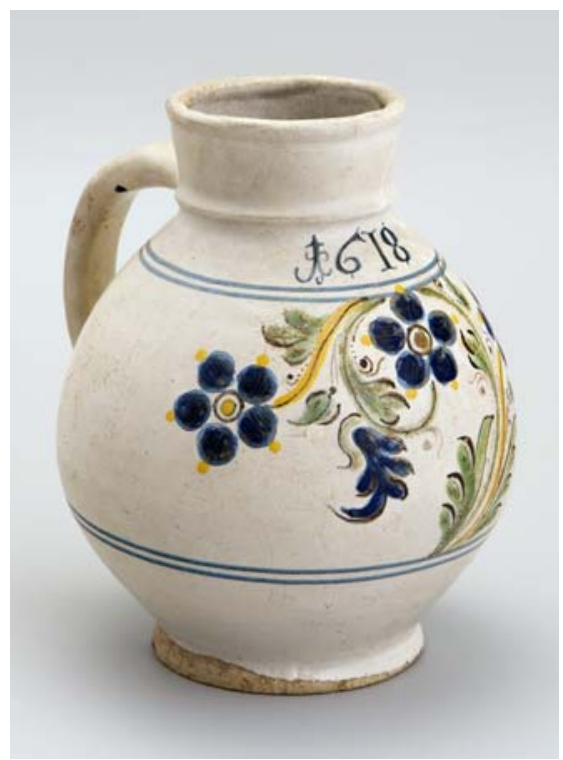

Fig. 7. Jug, 1618, faience, H. $17.1 \mathrm{~cm}$. Inv. n. U 29246

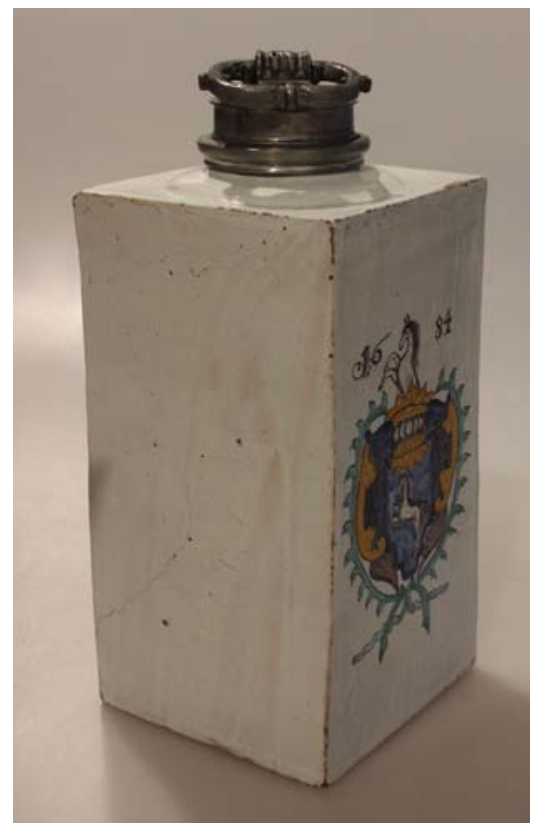

Fig. 9. Four sided bottle with crest, 1684, faience, H. $37.5 \mathrm{~cm}$. Inv. n. U 162

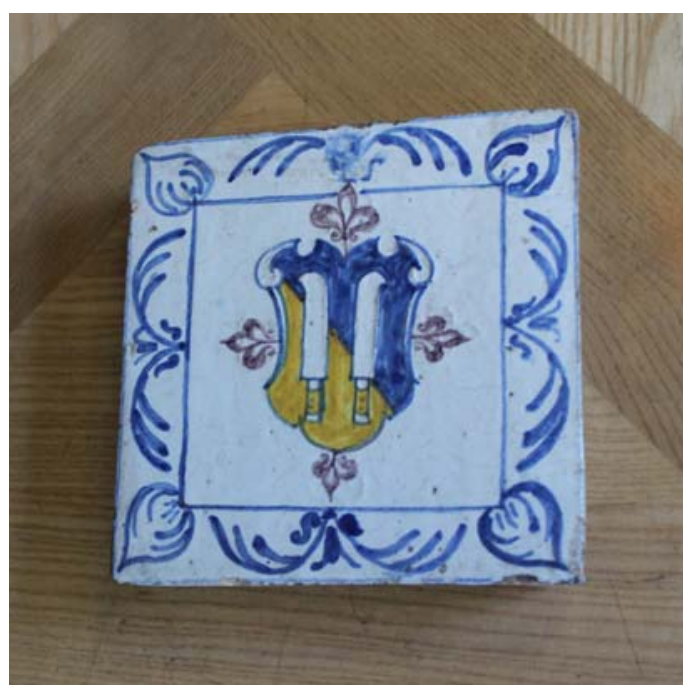

Fig. 8. Floor tile with the crest of Dietrichstein family, faience, $14.5 \times 14.5 \mathrm{~cm}$. Inv. n. U 14.044

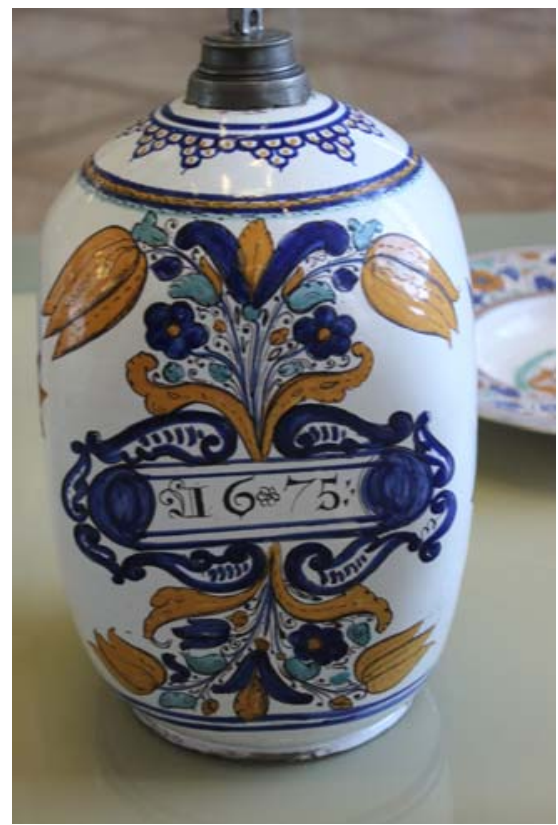

Fig. 10. Bottle, dated 1675, faiencen, H. $35 \mathrm{~cm}$. Inv. n. U 2216 


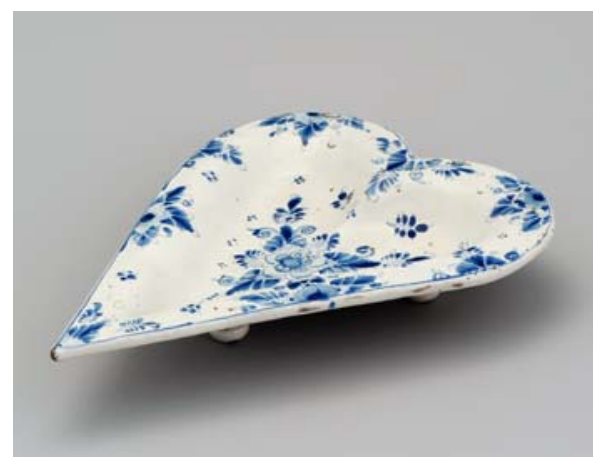

Fig. 11. Heart-shaped plate, faience, H. $22.8 \mathrm{~cm}$. Inv. n. U 30828

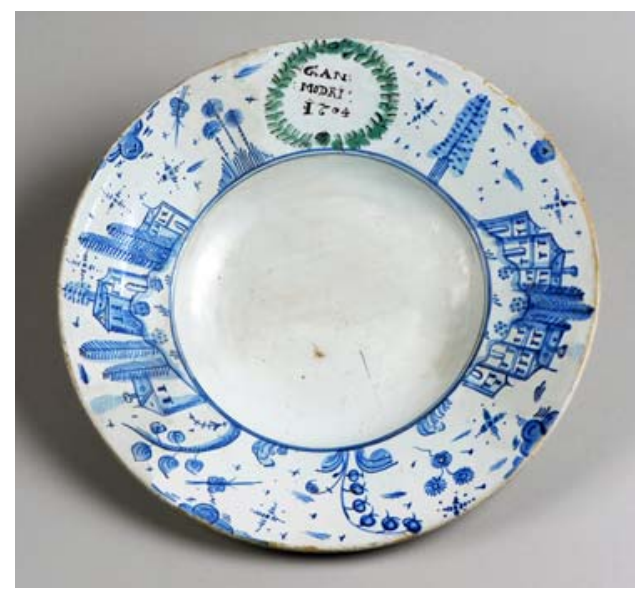

Fig. 12. Dish, faience, Ø $30 \mathrm{~cm}$. Inv. n. U 15259

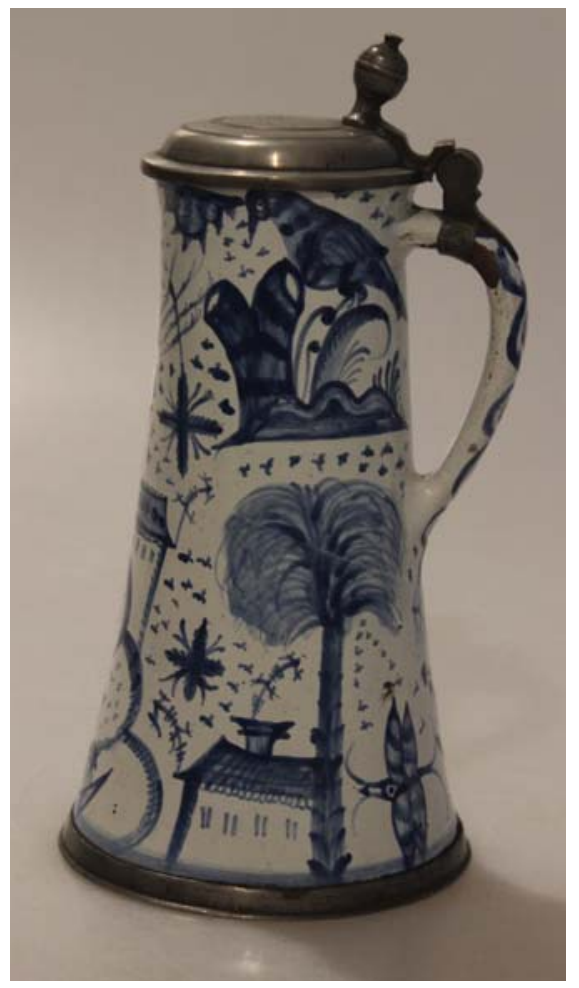

Fig. 13. Tankard, faience, H. 27.5 cm. Inv. n. U 9417 